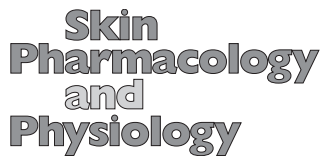

Skin Pharmacol Physiol 2006;19:62-64

DOI: 10.1159/000091971

Published online: May 9, 2006

\title{
Presenting Authors
}

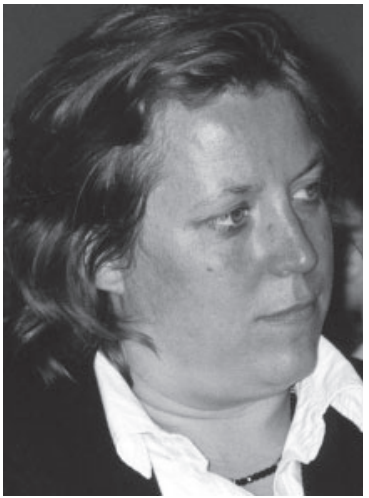

Dr. Carien Niessen

At the University of Utrecht, Dr. Niessen studied biology and obtained her M.Sci. in biology in 1991. Dr. Niessen did her $\mathrm{PhD}$ thesis on the interactions of the integrin $\alpha 6 \beta 4$ with the extracellular matrix and cytoskeleton at the Department of Cell Biology at the Netherlands Cancer Institute under the supervision of Dr. Arnoud Sonnenberg. After obtaining her PhD in 1996, Dr. Niessen received a Dutch Cancer Fellowship to work as a postdoctoral fellow in the laboratory of Dr. Barry Gumbiner at the Memorial Sloan Kettering Cancer Center. There she focused on the regulation of cadherin intercellular adhesion molecules.

In 2001 Dr. Niessen became a junior research group leader at the Center for Molecular Medicine Cologne at the Medical Faculty, University of Cologne.

Dr. Niessen has concentrated on research in the areas of intercellular adhesion in epithelial morphogenesis and pathogenesis with a focus on the role of intercellular adhesion molecules in epidermal biology.

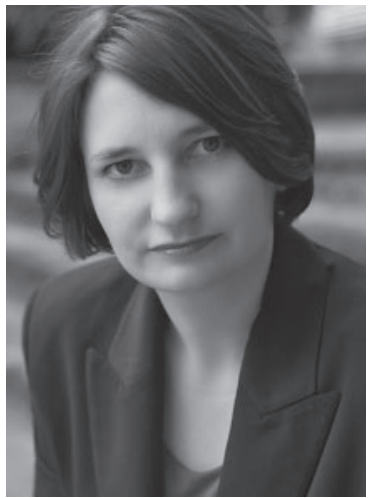

\section{Dr. Johanna M. Brandner}

At the University of Regensburg, Dr. Johanna M. Brandner studied biochemistry and obtained a degree in biochemistry in 1994. After her university education Dr. Brandner worked at the Division of Cell Biology at the German Cancer Research Center in Heidelberg as a PhD student under the supervision of Prof. Dr. Werner W. Franke. In 1998, she obtained her PhD in cell biology from Ruprecht-Karls-University in Heidelberg, specialising in nuclear and cell-cell junction proteins.

Since 1998 she has been the leader of the laboratory for Cell Biology at the Department of Dermatology and Venerology at the University Hospital Hamburg-Eppendorf.

Dr. Brandner has concentrated on research in the areas of epidermal barrier, especially tight junctions, and wound healing.

\section{KARGER}

(ㄷ) 2006 S. Karger AG, Basel

Fax +4161306 1234

E-Mail karger@karger.ch

www.karger.com 


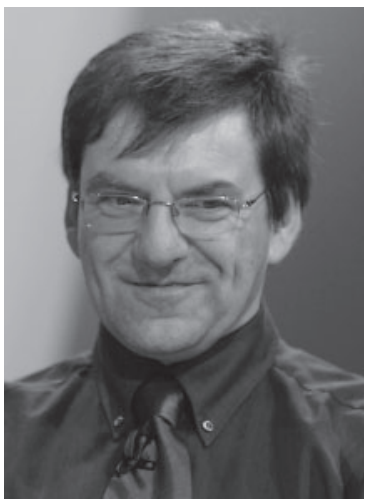

Prof. Dr. Karsten König

Dr. König studied physics at the Universities of Rostock and Jena and obtained his PhD degree in 1984 for his work on photodynamic therapy and optical diagnosis of tumours. He worked at the Institute of Laser Medicine at the University of Ulm, at the Beckman Laser Institute and Medical Clinic of the University of California Irvine, the Institute of Molecular Biologies in Jena and the Institute of Anatomy at the University of Jena. He got his habilitation degree for his work 'Biomedical applications of optical micromanipulation and multiphoton microscopy' in 1996.

In 2003 he became full professor at the Saarland University at the Faculty of Physics and Mechatronics as well as Head of the Department of Microsystems/Lasermedicine at the Fraunhofer Institute of Biomedical Technology (IBMT) in St. Ingbert.

Major research fields include high resolution optical biopsies, gene therapy and nanoprocessing with femtosecond lasers. He is the author of more than 200 scientific papers.

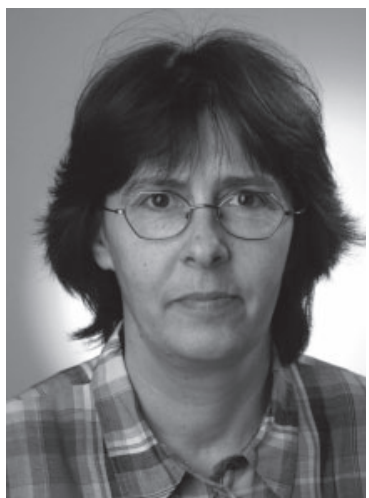

\section{PD. Dr. Karin Müller-Decker}

Dr. Müller-Decker studied biology at the Universities of Saarbrücken and Heidelberg and obtained her diploma in biology in 1984, her PhD in 1988. Her PhD work was about the mechanism of an antiviral compound tricyclodecane-9-yl-xanthate and was done at the Department of Molecular Biology of DNA Tumor Viruses headed by Dr. G. Sauer, DKFZ Heidelberg. With a grant from the Management Board, Chairman and Scientific Member of the DKFZ, Dr. Müller-Decker worked as a postdoctoral fellow from 1988 to 1989 on TPA-induced signalling and inhibitors of PC-specific phospholipase $\mathrm{C}$ at the department of G. Sauer. Her postdoctoral work continued at the Department of Biochemistry of Tissue-specific Regulation headed by Dr. F. Marks, DKFZ. Her work dealt with the development of a mechanism-based in vitro skin irritancy test and pro-inflammatory mediators as indicators of primary irritant dermatitis and the validation of an in vitro skin irritancy test by a controlled clinical study (the topic of her habilitation). In 1999, she received the Venia Legendi for Experimental Dermatology (Medical Faculty, Ruprecht-Karls-University, Heidelberg) and in 2002 for Biochemistry (Faculty for Life Sciences, University, Heidelberg).

Since 1999 Dr. Müller-Decker has been head of the project group Cyclooxygenases and Tumor Development within the section of Eicosanoids and Tumor Development headed by Dr. G. Fürstenberger.

The focus of her work is on the functional role of cyclooxygenases in epidermis and other epithelia under physiological and pathological conditions. 


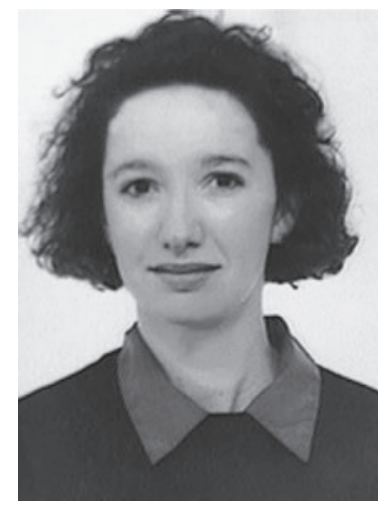

\section{Dr. Emmanuelle Noblesse}

At the University of Caen (France), Dr. Noblesse studied biology and biochemistry and obtained a degree in biochemistry in 1996. After her university education Dr. Noblesse worked at the Skin Substitute Laboratory at Edouard Herriot Hospital in Lyon from 1997 to 2002 and obtained her $\mathrm{PhD}$ in cellular and tissular biology in 2003.

Since April 2002, she has been employed by LVMH as a project manager at the LEAP laboratory (skin biology research laboratory).

Dr. Noblesse has concentrated on research in the area of skin imagery for cosmetic products research and development.

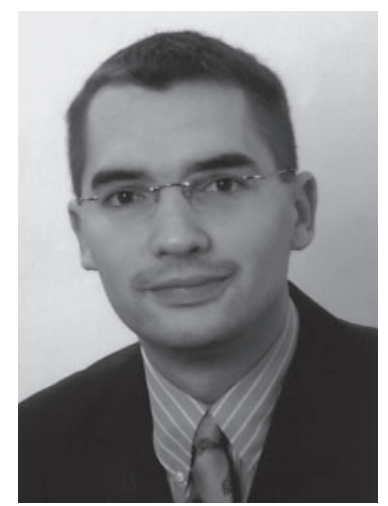

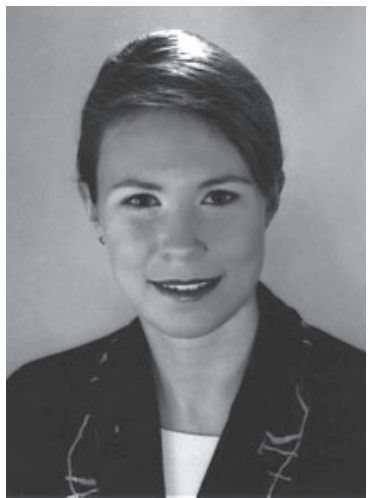

Dr. Alexa Teichmann

Dr. Teichmann studied medicine at the Humboldt University of Berlin and obtained her degree in 2004. She wrote her doctorate in 2004 on the topic 'Reservoir function of the stratum corneum'.

In 2004, Dr. Teichmann began her residency in dermatology at the Department of Dermatology, Charité, Universitätsmedizin Berlin, Center for Experimental and Applied Cutaneous Physiology.

Her research work concentrates on the areas of percutaneous penetration pathways, in particular on the follicular penetration pathway of topically applied substances, investigated by different spectroscopic non-invasive in vivo techniques.

\section{Dr. Hagen Trommer}

Dr. Trommer studied pharmacy at the Martin Luther University Halle-Wittenberg and obtained a degree in pharmacy in 1998. After his university education Dr. Trommer worked as a scientific associate at the Institute of Pharmaceutical Technology and Biopharmaceutics of the University in Halle investigating the mechanism of oxidative stress by use of stratum corneum lipid model systems. In 2002, he obtained his PhD in natural sciences at the Martin Luther University Halle-Wittenberg.

Since 2003 Dr. Trommer has been Process Validation Manager at the solid drug forms producing plant of Bayer Healthcare in Bitterfeld.

Dr. Trommer has concentrated on research in the areas of UV-induced damage of skin biomolecules, instrumental analytics of skin constituents, skin penetration and skin protection. 